\title{
Field experience of using guided waves for corrosion monitoring of piping
}

\section{Doświadczenia ze stosowania kierowanych fal ultradźwiękowych do monitorowania korozji rurociągów}

\section{Abstract}

DEKRA Industrial $A B$ has used Guided Waves Ultrasonic Technique (hereafter called GWUT) for some years now. During time, DEKRA has acquired a lot of field experience with this technique and together with customers tried to find the limits of the technique. This article gives an overview on the technique and shows some results from field testing. Nonetheless of the experience acquired, DEKRA and its customers are still trying to find new possibilities for using the technique and find new areas to employ it.

\section{Streszczenie}

DEKRA Industrial AB już od kilku lat stosuje technikę ultradźwiękową fal kierowanych (dalej nazywaną GWUT). Podczas tego okresu DEKRA zdobyła wiele praktycznych doświadczeń w stosowaniu tej techniki oraz wraz z klientami próbuje znaleźć jej ograniczenia. Niniejszy artykuł stanowi zwięzły opis podstaw techniki GWUT i prezentację wybranych wyników badań w terenie. Niezależnie od zdobytych już doświadczeń DEKRA wspólnie z klientami wciąż próbuje znaleźć nowe możliwości i obszary zastosowania tej techniki.

\section{Introduction}

DEKRA Industrial AB has used Guided Waves UItrasonic Technique (hereafter called GWUT) for some years now. During time, DEKRA has acquired a lot of field experience with this technique and together with customers tried to find the limits of the technique. This article gives an overview on the technique and shows some results from field testing. Nonetheless of the experience acquired, DEKRA and its customers are still trying to find new possibilities for using the technique and find new areas to employ it.

Simon Niederhauser, Robert Ernst - DEKRA Industrial AB.

\section{Guided waves technique}

GWUT is a system to screen pipes for defects and gives the position of such defects with a good accuracy. The first image, see Fig. 1, shows all the system components. The transducer rings are fitted for the different pipe sizes and for larger pipes two rings can be joined. The ring is connected to the G3 where the information is stored during testing. Finally, a computer is necessary to analyse the data files.

GWUT is using low frequencies in the range of about 20 to $80 \mathrm{kHz}$. The ultrasonic waves emitted are torsional waves and are guided through the walls of a pipe in both directions. At each feature that is associated with a change in cross-sectional area, a part of the wave is mirrored back to the transducer, see Fig. 2. 


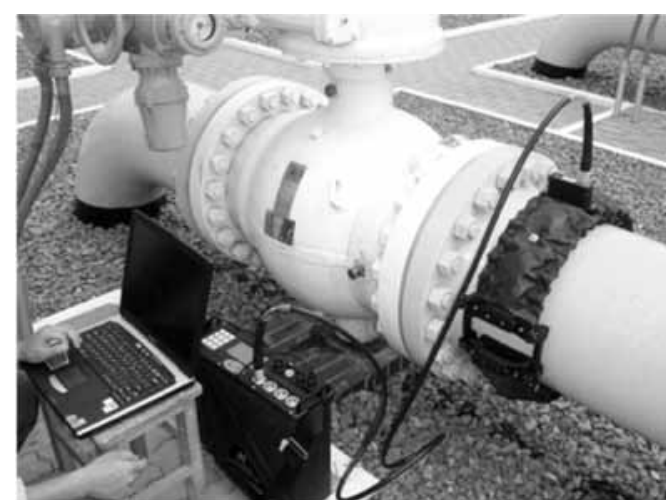

Fig. 1. The GWUT components: To the right is an inflatable ring that contains the transducers mounted around the pipe. The ring is connected to the $\mathrm{G} 3$ instrument (black, stands on the ground) by a connector cable. From the G3 the information is loaded onto a computer where the analysis is made

Rys. 1. Składniki system GWUT: Po prawej jest widoczny na rurociągu pierścień zawierający przetworniki. Pierścień jest podłączony kablami do aparatu G3 (czarny stojący na ziemi). Z aparatu G3 zebrane dane są przesyłane do komputera, gdzie może być wykonana ich analiza

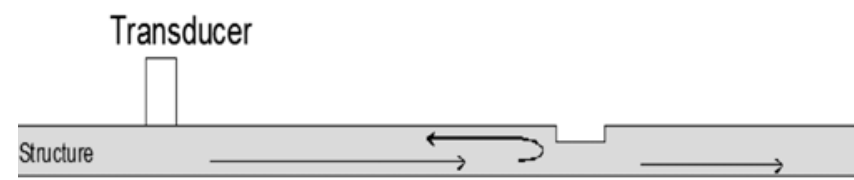

Fig. 2. The mirroring effect at a cross-sectional change. The rest of the wave is propagating further in the pipe

Rys. 2. Efekt odbicia fal na zmianie przekroju ścianki rury. Pozostała, nieodbita część fali rozchodzi się dalej w ściance rury

The time from emitting the wave until the mirrored signal is detected gives the distance to the feature. The amplitude of the mirrored wave depends on the size of feature. If the feature is symmetric, i.e. all around the circumference such as a weld, the mirrored signal consists also of a torsional wave. On the other hand, if the signal is asymmetric, i.e. only part of the circumference such as a corrosion patch, the mirrored wave consists of a torsional wave and of a flexural wave. These two parts of the wave contain different information. The torsional wave is indicating the size of the feature, whereas the flexural wave contains the information about the extent of asymmetry and position around the tube.

The wave that is transported in the pipe is losing energy on its way. First, there is an exponential decay that is proportional to the distance from the transducer ring. Second, the wave is losing a part of the energy at every mirror place. Welds are used to set a reference line for this attenuation by setting so-called weld-DAC curves. These weld-DAC curves are then used as reference lines for the evaluation. Fig. 3 shows a typical result of a GWUT test. There is the black signal that is the torsional waves recorded by the transducer, the red signal that gives the information about the circumferential extent (flexural mode), the upper; dotted line is the weld-DAC and the lower, dotted line the call-DAC.

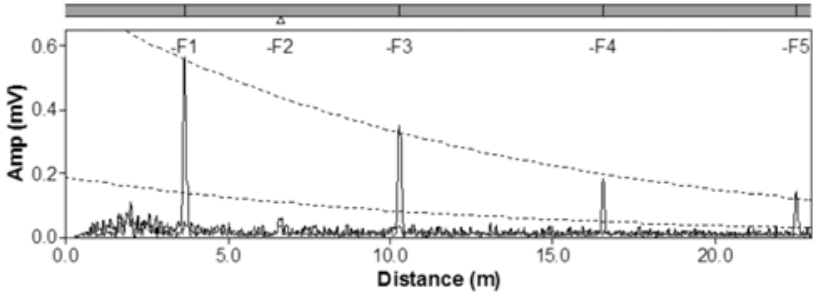

Fig. 3. A typical GWUT result, only positive direction is shown. The upper line is the weld-DAC curve linked to the welds, the lower line is the call-DAC. Features above this line should be marked

Rys. 3. Typowy obraz GWUT, tylko dla dodatniego kierunku rozchodzenia się fali. Górna linia przerywana to tzw. krzywa DAC-spoin związana ze złączami obwodowymi, dolna linia jest krzywą oceny tzw. call-DAC

The cross-sectional change associated with a weld is most often $20-25 \%$ of the cross section. At $7 \%$ crosssectional change there is the call-DAC. Features that are larger than this size should be checked by another method, i.e. visual inspection or thickness testing with manual ultrasonic technique. For features below $7 \%$ of cross-sectional change the extent of asymmetry should also be taken into account. Smaller features that are very local, which results in a large red signal compared to the black signal should be marked as features to follow up as well.

\section{Field experience}

Many tasks have been obtained by DEKRA for GWUT testing. Some of the limitations of the systems, e.g. the inspection range is too short, place to apply the equipment and the like, are easily communicated and understood by the customer. However, in many cases first tests have to be done in order to see and evaluate the actual pipes.

An experience that DEKRA has acquired is the handling of heating pipes along the testing pipes. As long as they can be switched off, the handling is rather easy and the heating pipes are bent out in order to have

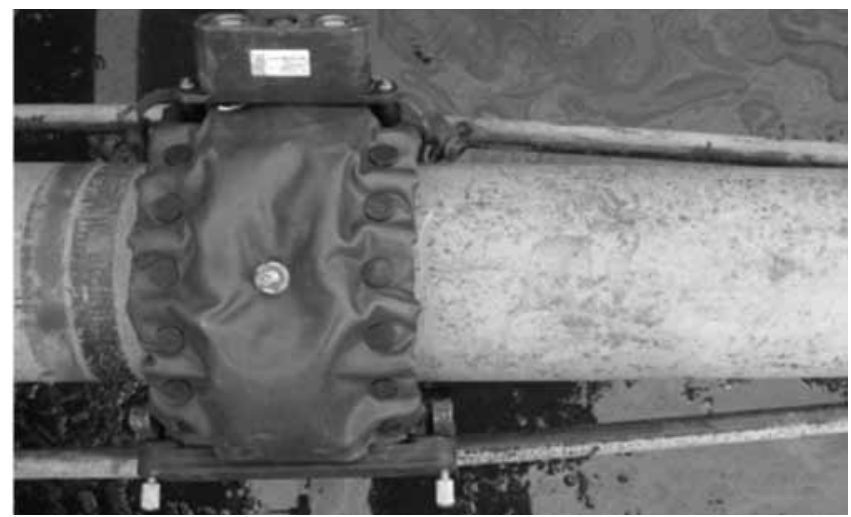

Fig. 4. An applied ring on a tube and two heating pipes that are bent out for application of the ring

Rys. 4. Założony na rurociąg pierścień głowic i 2 rury grzewcze odgięte, aby ułatwić montaż pierścienia 
the space necessary to apply the ring. In such cases it is not important whether the heating pipe is touching the ring or not, see Fig. 4. On the other hand, if the heating pipes are still hot, a work around is to use e.g. a welding cloth between the ring and the heating pipes in order to stop direct heat transfer and not to damage the ring.

The effect of the media in the pipe is not always predictable. In general terms, it can be said that gases and low viscous liquids have no effect, but that high viscous liquids such as sludge attenuate the signals. The more attenuation the media gives, the shorter is the inspection range. However, there had been examples where the inspection was rather short. The information given to DEKRA can in such cases be that there is water in the pipe. Nonetheless, if the water is waste water the media can be highly attenuate and limit the range. DEKRA has experienced that the best is to give it a try and then make the conclusions of whether it works or not and how long the inspection range can calculated with.

It has also be shown for larger projects that a first visit to the site and the discussion with the customer has a beneficial effect on the outcome of the work, the time used, and the results. Especially on older sites where sometimes the drawings are not up to date, a first visit can give a hint about obstacles to overcome before

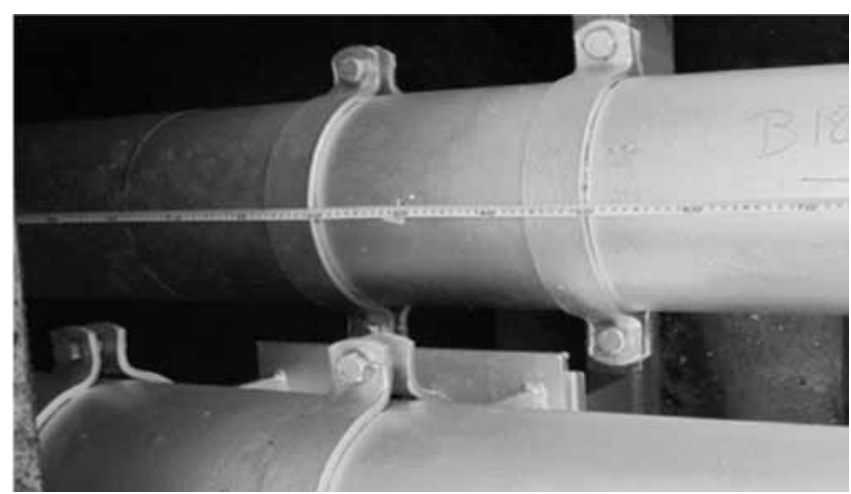

Fig. 5. Supportin clamps on the pipes

Rys. 5. Klamry podtrzymujące lub zawieszające rurociągi

testing is taking place. Features that often have shown taking time are clamped supports, see Figure 5. If the clamping of the support in such cases is too hard, the signals can attenuate to an extent that no inspection is possible behind the clamps. A loosening of the clamps can, however, solve the problems. In cases where the tubes are insulated, this operation can become more difficult or time consuming. A good planning of the work with a try of the GWUT technique prior to the inspection can avoid this problem. Note, the possibility to shoot at one position does not always result in the possibility to inspect at another position.

\section{Conclusions}

DEKRA Industrials has now an extensive field experience acquired. The method has shown that even rather small defects can be detected and a scanning of $100 \%$ of the tube is most often possible. Additionally, the customers have hitherto shown great interest to experiment with the technique and find the limitations of it. The following conclusions can be drawn from our field experiment:

- The length of inspection and the size of defects measureable is linked to the general quality of the tube

- Bends with larger radius or bended tubes with large radius can be inspected. The signal is split into two for larger distances.
- Large tubes give often red signals in welds. These signals are often linked to the offset seen in this tube.

- The technique has its greatest advantage for tubes that are difficult to access, with buried or sleeved pipes, and with insulated tubes.

The best results have been obtained with customers that know the technique as well as its possibilities and limitations very good. In such cases the dialog between DEKRA and the customer is facilitated and the tasks of testing are appropriate for the technique. In such cases, the interpretation of the results can be followed by the customer. 